\title{
Appendix 2: The final report of the Special Rapporteur on multiple reforms in Cambodia
}




\section{General Assembly}

Distr.: General

15 August 2014

Original: English

Human Rights Council

Twenty-seventh session

Agenda item 10

Technical assistance and capacity-building

\section{Report of the Special Rapporteur on the situation of human rights in Cambodia, Surya P. Subedi}

\section{Summary}

The present report reflects on the work of the Special Rapporteur, Professor Surya Subedi, for the past six years in general and the past 12 months in particular. The Special Rapporteur has had the privilege of serving as the Special Rapporteur on the situation of human rights in Cambodia since May 2009. It gives him pleasure to state that the situation in Cambodia has come full circle during the intervening six years and the country is currently in the process of peaceful political transition. These years have been stimulating, intellectually challenging and rewarding at the same time for the Special Rapporteur. He finds it gratifying to report that some of his recommendations have been implemented and others are in the process of being implemented by the Government.

The focus of the Special Rapporteur during the reporting period (1 July 201324 July 2014) has been on the possibility for the establishment of an independent national human rights institution that meets the benchmarks of the principles relating to the status of national institutions for the promotion and protection of human rights (the Paris Principles) and on the implementation of the recommendations contained in his previous four substantive and substantial reports dealing with judicial, parliamentary, electoral and land reform in Cambodia. The Special Rapporteur focused his last two missions to the country — conducted in January and in June 2014 - on those two objectives and continued to monitor the situation of human rights in Cambodia.

The Special Rapporteur was welcomed by the Government during his two missions to the country in January and June 2014. He was able to meet with senior members of the Government of Cambodia, including the Prime Minister, who assured him that many of his recommendations were being implemented and that those specifically relating to judicial and electoral reform would be implemented in the near future. The Prime Minister was receptive to the idea of establishing an independent national human rights institution that meets the Paris Principles.

Cambodia witnessed major political events during the reporting period, including elections to the National Assembly in July 2013. The elections were conducted in a largely peaceful manner, but were marred by allegations of electoral irregularities. Calling for an 
independent and credible investigation into those allegations, the newly elected members of Parliament belonging to the opposition party the Cambodia National Rescue Party (CNRP) refused to take their seats in the National Assembly. In the aftermath of the elections, people were for the most part able to express themselves freely and to enjoy their freedom of assembly through numerous protest marches and demonstrations, both large and small. Those protests were mostly well disciplined and peaceful and were in general not subject to restriction by the authorities. The sharing of views and information through new means, particularly social media, enabled more ordinary people to take interest and directly participate in the national political and economic discourse than ever before. The Special Rapporteur believed that the ability of people to exercise their rights was a sign of a maturing democracy in Cambodia, which he welcomed. On 22 July 2014, the two parties finally ended their stand-off by reaching an agreement on several key issues, and CNRP announced that it would assume its seats in the National Assembly. However, the violence and use of excessive force witnessed on repeated occasions since the elections, as well as the indefinite continuation of an ambiguous and arbitrary ban on demonstrations that lasted over six months at the time of writing, and the arrest of CNRP members on very serious charges widely believed to be politically motivated, ran counter to this trend.

The international community has invested heavily in Cambodia; however, some of the State institutions, such as the judiciary and the National Election Committee, have not been able to command the full trust and confidence of the entire population. The Special Rapporteur welcomed in principle the enactment of three fundamental laws on the judiciary which had constituted the core of the recommendations in his first substantial report in 2010. Those laws contain a number of provisions designed to strengthen the workings of the judiciary, for instance, in regard to case management. Although the Special Rapporteur is concerned by certain provisions in those laws which are detrimental to the independence of the judiciary and the doctrine of the separation of powers, the laws passed by Parliament should provide a framework for improvement in the future. With regard to parliamentary and electoral reform, the long overdue reform has become more urgent now than ever and the Special Rapporteur has made further recommendations in the present report.

The Special Rapporteur is encouraged by the acceptance of the rationale and the need for electoral reform contained in his report on electoral reform $(\mathrm{A} / \mathrm{HRC} / 21 / 63)$ by both the ruling and opposition parties. He hopes that, in addressing those fundamental issues, the two parties will reach a logical conclusion on principled grounds, rather than be guided merely by political expediency of a temporary nature. This is an opportunity to carry out a comprehensive reform of lasting character informed by international standards so that the situation that arose following the 2013 elections to the National Assembly will not repeat itself. By virtue of the fact that it is the ruling party, the Cambodian People's Party and the Government itself have the responsibility to demonstrate maximum flexibility, leadership and seriousness and embrace the demands for reform to ensure a smoother functioning of democracy in the country. At the same time, the opposition party too must be reasonable and realistic and promote tolerance and harmonious race relations.

The overall assessment of the Special Rapporteur of the situation of human rights is that it is evolving in a generally positive direction, and he remains optimistic for the longterm development of the nation. He welcomes the end of the political stalemate, which now makes it possible to make meaningful progress towards building a governance structure that protects and respects human rights. This is the final report of the present Rapporteur for the Human Rights Council. 


\section{Contents}

Paragraphs Page

I. Introduction

1-62 4

A. Overall situation of human rights............................................................ $\quad 9$

B. Communications sent to the Government ...................................................

C. Reform of the judiciary ...................................................................... $\quad 34-40 \quad 10$

D. Reform of Parliament ........................................................................ $41-43 \quad 11$

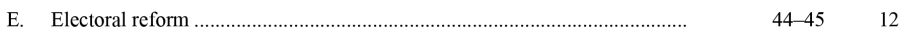

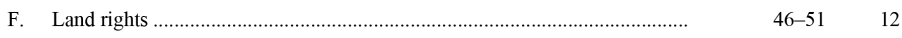

G. Emerging issues ...................................................................................

II. Universal periodic review of Cambodia …........................................................... $\quad 63-77 \quad 15$

The independence of national human rights institutions...........................

III. Conclusions ......................................................................................

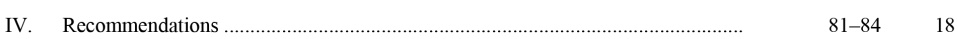




\section{Introduction}

1. Since the maximum term of a Special Rapporteur is six years, and the current Special Rapporteur's term is now in its sixth year, the present report is the last he will submit to the Human Rights Council in his present function. He thanks warmly the Government of Cambodia, the leaders of both the ruling and the opposition party, members of civil society, the United Nations country team in Cambodia, and the Geneva and Cambodia Offices of the United Nations High Commissioner for Human Rights which have facilitated and supported his work. He also wishes to thank the Council for placing its trust and confidence in him by appointing him to the position in March 2009 and for renewing his appointment annually and for an unprecedented term of two years on two occasions which provided him the stability needed to concentrate on a more strategic approach to the protection and promotion of human rights in Cambodia. The present, final report will partly take stock of the progression of his work, provide an update on the situation covering the developments of the past 12 months and offer recommendations for the future.

2. The present report is the sixth report of the present Special Rapporteur on the situation of human rights in Cambodia submitted pursuant to Human Rights Council resolution $24 / 29$ of 27 September 2013, requesting him to report on the implementation of his mandate.

3. During the year under review, the Special Rapporteur continued to monitor the situation of human rights in Cambodia. He continued to receive information on the situation of human rights from different stakeholders in Cambodia, including the Government, the opposition political parties, civil society organizations and citizens, some of whom sought the help of the Special Rapporteur in addressing alleged violations of human rights in the country. He conducted two visits during the review period - one in January 2014 and the other in June 2014. The Government resumed its regular mode of cooperation with the Special Rapporteur, enabling him to meet with a broad range of actors within the Government.

4. In January 2014, the Special Rapporteur met with Prime Minister Hun Sen, in the presence of many other senior ministers. He also interacted with other stakeholders in Cambodia, including the leaders of the opposition party, ordinary citizens, groups of youths and students, representatives of civil society organizations and members of the international community, including development partners and the United Nations country team. At the outset, the Special Rapporteur wishes to express his appreciation to the Government of Cambodia for the positive and constructive cooperation extended to him during his missions. The dialogue he had with the Prime Minister was frank, cordial and informative. As the Special Rapporteur has emphasized in the past, in the delivery of his mandate as entrusted to him by the Council, it is crucial that he be able to have a meaningful dialogue with all actors in the Cambodian society, particularly with the Government. The Prime Minister sent an important signal to the international community by constructively engaging with the Special Rapporteur that he was ready and willing to seriously address the human rights issues in the country.

5. During his mission in June 2014, the Special Rapporteur met with Sar Kheng, Deputy Prime Minister and Minister of the Interior, Om Yentieng, Senior Minister and Chair of the Cambodian Human Rights Committee, Im Chhun Lim, Senior Minister and Minister of Land Management, Urban Planning and Construction, Ith Sam Heng, Minister of Labour and Vocational Training, senior members of the judiciary and the Governor and Deputy Governor of Preah Sihanouk province. The Special Rapporteur also interacted with a large number of other stakeholders, including a broader range of human rights 
organizations dealing with women's, disability and lesbian, gay, bisexual and transgender and intersex rights.

6. In assessing the progress made by the Government in establishing an independent human rights institution, the Special Rapporteur focused on the independence of those State institutions that are responsible for monitoring human rights and ensuring that remedy is provided where violations are found to have occurred. The Special Rapporteur considers that many of the issues highlighted in his earlier reports and the high level of dissatisfaction revealed at the last parliamentary elections reflect a failure to protect the human rights of a large number of Cambodians who claim to have been disenfranchised and/or displaced or who are economically, politically and otherwise vulnerable.

7. That the outcome of the elections should have come as a surprise to many may be due to the absence of the kind of independent national institutions that should have monitored the pressing human rights and governance issues of the nation, been able to alert decision makers wherever problems are found and exercise the authority necessary to rectify those problems as needed. While social problems, dissatisfaction and complaints will always exist, appropriate independent institutional mechanisms could have addressed them before they became divisive social issues. There is an urgent need to reconsider the official position toward such institutions, which in general has been to establish governmental institutions rather than independent ones, which, with rare exceptions, have failed to prove effective and gain the trust of the public.

8. On the eve of finalization of the present report, the Special Rapporteur learned that the two parties finally reached an agreement to end the longest running political stalemate in decades. The Cambodia National Rescue Party (CNRP) will assume its seats in the National Assembly, which can now fulfil its purpose as a national platform for debate and compromise on the national legislative and policymaking agenda. He warmly welcomed that news with a public statement and expressed the hope that it would mark the start of the critical promised reforms.

\section{A. Overall situation of human rights}

9. Up to the end of 2013, the assessment of the Special Rapporteur of the evolution of the situation of human rights was generally a positive one. During his previous missions and in his earlier reports, the Special Rapporteur had called on the Government to enable the leader of the opposition, Sam Rainsy, to return to the country from exile and to take an active part in the politics of the country. The Special Rapporteur was pleased when Mr. Rainsy was granted a royal pardon in time to lead his party in the elections in July 2013.

10. The Special Rapporteur noted that the elections were conducted in a largely peaceful manner, but were marred by allegations of electoral irregularities. Calling for an independent and credible investigation into those allegations, CNRP refused to take its seats in the National Assembly. The irregularities were reported by several organizations and groups of organizations that monitored the elections. Those groups were largely consistent in their findings despite slight differences. ${ }^{1}$

1 In November 2013, the Electoral Reform Alliance, comprised of some 20 civil society organizations, set out joint findings in a report on the conduct of the elections. Electoral Reform Alliance, "Joint report on the conduct of the 2013 Cambodian elections". Available from http://nationalrescueparty.org/wp-content/uploads/2013/11/FINAL-ERA-REPORT.NDI .pdf 
11. In the fulfilment of its constitutionally mandated duties, the National Election Committee speedily took up election complaints but then proceeded to dismiss each one. While the Committee recognized that some irregularities might have occurred, it concluded that none were so grave as to affect the results of the elections. The same conclusion was reached at the next stage, when the Constitutional Council reviewed the complaints.

12. The Special Rapporteur noted with satisfaction that, in the aftermath of the elections, people were for the most part able to express themselves freely and to enjoy their freedom of assembly through numerous protest marches and demonstrations, both large and small. With some exceptions, they were well disciplined and peaceful and in general not restricted by the authorities; at many of them the traffic police played a helpful role. At the same time, most demonstrations were met with barriers with barbed wire and security forces equipped with electric batons and shields, guns, slingshots, metal bars and other makeshift weapons. Nevertheless, the Special Rapporteur believed that the ability of people to exercise their rights and freedoms was a sign of a maturing democracy in Cambodia, which he welcomed.

13. However, on several occasions the peace was broken by violence and security officials resorting to excessive force. That was the case on 15 and 22 September and 12 November 2013, and on 2, 3 and 4 January 2014, when demonstrations of varying scale were violently broken up by security forces. On several occasions, security forces caused crowds to be formed at road-barriers, blocking commuters from crossing certain roads and bridges; on one occasion on 15 September, they opened fire on the crowd, killing one bystander and injuring many others. The authorities visibly targeted journalists covering a small demonstration on 22 September. World Press Freedom Day 2014 in Cambodia was ironically marked by front-page coverage of journalists being beaten and cameras confiscated as they observed small demonstrations during the preceding days.

14. The number and scale of the demonstrations increased toward the end of the year from monthly to weekly to daily protests by December as the political opposition called for the Prime Minister to step down. When negotiations for raising the minimum wage broke down on 23 December as the Ministry of Labour and Vocational Training set a new minimum wage that constituted a smaller increase than that sought by the major independent trade unions, labour protests converged with the demonstrations by the political opposition. By now, tens of thousands of persons were joining the mass demonstrations.

15. Few were prepared for the shocking response of early January. On 2 January, military soldiers guarding the Yakjin factory as workers demonstrated outside descended into the crowd, indiscriminately beating demonstrators and arresting 15 people. Ten of them, several of whom had sustained serious injuries, were detained incommunicado for days, moved to a remote prison, and later charged with intentional violence and destruction of property.

16. The following morning, military police fired live ammunition when a demonstration in an industrial area on the outskirts of Phnom Penh turned violent, killing four ${ }^{2}$ and injuring scores more. At least 13 people were arrested and later charged with intentional violence and destruction of property, including one minor.

17. On 4 January, security forces cleared demonstrators and bystanders from Freedom Park, a central area in Phnom Penh designated for demonstrations that had become the epicentre of gatherings of the opposition. On the same day, notifications were issued by the

\footnotetext{
2 A fifth person who sustained serious injury died at a later date, and the sixth, a minor, remains missing after he was last seen having been shot in the chest.
} 
Phnom Penh Municipality, the Ministry of Interior and the Ministry of Foreign Affairs and International Cooperation stating that demonstrations by marches or public rallies, including at Freedom Park, would no longer be allowed until public security and order was restored. At the time of writing, Freedom Park remained surrounded by razor wire and metal barricades, preventing access to the area from all sides.

18. While the Special Rapporteur condemned the violence used by some demonstrators, the actions of the authorities in suppressing the protests in the first week of January 2014 constituted a disproportionate response. They marked a worrying change in policy from a tolerant to a repressive response to public protests. Those events and the treatment of the 23 individuals detained became further motivation for civil society organizations and have been internationally condemned.

19. The Special Rapporteur regrets that no thorough, credible and independent investigation has yet been carried out into the incidents, adding to the long list of cases in which perpetrators of violence have not been brought to justice. Impunity remains a serious concern in Cambodia. The Government has the obligation to ensure that any use of force meets the tests of necessity, legality and proportionality, to explain how it meets those tests, and to ensure that perpetrators of violence are held accountable.

20. The lack of action against the members of the security forces who opened fire on the crowds or otherwise committed acts of violence in the incidents described above contrasts with the speed of proceedings against the individuals not members of the forces whom the authorities charged with violence. Those arrested in connection with the incidents were charged within days; all but two were convicted despite the lack of any material evidence proving their direct involvement in acts of violence. In the case of the 25 charged in relation to the events of 12 November 2013 and 2 and 3 January 2014, the Special Rapporteur welcomed their release but noted with concern the faulty legal proceedings that led to their convictions.

21. The Special Rapporteur communicated his concern at the ban on demonstrations during his mission in January, as well as in a follow-up allegation letter dated 17 February 2014, that the Government had not clarified the legal basis and justification for such a ban. The right of peaceful assembly is protected under article 21 of the International Covenant on Civil and Political Rights, to which Cambodia is a party. Under article 4 of the Covenant, measures derogating from obligations set out therein can only be taken to the extent strictly required by the exigencies of the situation, and only in time of public emergency which threatens the life of the nation and the existence of which is officially proclaimed. The Special Rapporteur has not seen an official proclamation of a public emergency of such gravity that it threatens the life of the nation. At the time of drafting, despite public pronouncements to the contrary, the ban remained in force, although some demonstrations have selectively been allowed to proceed. The environment is therefore one of uncertainty and arbitrariness.

22. As the ban continued with no signs of being lifted, members of the opposition decided to move directly on Freedom Park. For several weeks during the first half of 2014, CNRP member Mu Sochua visited the Park daily and was prevented from entering it by military police. On 15 July 2014, she and other CNRP Members of Parliament elect gathered there with several hundred supporters to call for a lifting of the ban. A peaceful show of defiance through a banner reading "Free the Freedom Park" being placed on the barbed wire, to which district security guards reacted by beating protesters. When they retreated, several guards who became isolated among the protesters were themselves beaten, some severely. Four opposition Members of Parliament elect and one supporter were arrested that day, and three more Members of Parliament elect were arrested in the days that followed. Despite the guards' conduct, which the Special Rapporteur condemns, 
he regrets the violence to which they were subjected and issued a statement urging calm and calling for an investigation into the incident.

23. With regard to the question of minimum wage that has been at the centre of recent labour disputes, the Special Rapporteur viewed with concern the inability of the existing mechanism to set a minimum wage that responded to the needs of both workers and employers on the basis of objective data. The existing mechanism - the tripartite Labour Advisory Committee which advises the Ministry of Labour - has reportedly been more of a forum for undertaking negotiations than for providing technically sound analysis and advice. The Special Rapporteur thus welcomes the encouraging signs that a mechanism might soon be established that will be more transparent and participatory than has been the case to date.

24. In his interaction with various stakeholders on labour issues, the Special Rapporteur was concerned to hear that some workers and trade union leaders had faced threats and acts of intimidations as a result of their involvement in industrial actions. In that connection, he is alarmed by the upsurge of judicial intimidation of union activists in April and May, which included arrests in Kandal, Kampong Speu and Takeo provinces, as well as the imposition of an unprecedented bail bond of US\$25,000 in the case against the leader of the country's largest independent union, Ath Thun, who faced incitement charges that were later dropped in July 2014.

25. The Special Rapporteur maintains his view that the human rights situation in Cambodia, viewed from a long-term perspective, is heading in a generally positive direction. That is due mostly to the emergence of an emboldened population who came forward en masse to express its views in 2013. It did so in an impressive, disciplined way, despite the acts of stone-throwing and the destruction of property by some protesters, and fortified barriers and the presence of armed security forces. He believes that the general population experienced a political awakening in 2013 and is consequently hopeful that new ways will be found to meet the rising expectations of the increasingly aware and demanding Cambodian people. He notes with satisfaction that the supporters of the ruling party, who by the official election results amount to about half of the population, have also shown tolerance towards the opposition by generally not acting out on the threats occasionally made about holding counter-demonstrations, albeit with several notable exceptions. The Special Rapporteur underscores that openness, tolerance and spirit of common purpose, in full recognition of the right of to disagree with one another, are essential foundations for a functional democracy.

26. On the other hand, that generally positive trend has not been accompanied by any significant changes in the general architecture of governance. Several major initiatives have been announced and some have been enacted, but the level of implementation remains to be assessed. On the contrary, developments in the areas of judicial reform, the restrictive direction in which the law-making process generally appears to be headed, the continued restrictions on freedom of expression and assembly, and the lack of investigations into the use of excessive force by security forces since last September all cast doubt on the prospect for meaningful reform, and the two main parties must now overcome those obstacles.

\section{B. Communications sent to the Government}

27. During the reporting period, the Special Rapporteur addressed a number of communications to the Government on specific cases of concern as outlined below.

28. On 27 September 2013, a joint urgent appeal was sent with the Special Rapporteur on the promotion and protection of the right to freedom of opinion and expression, the Special Rapporteur on the rights to freedom of peaceful assembly and of association, the 
Special Rapporteur on the situation of human rights defenders and the Special Rapporteur on torture and other cruel, inhuman or degrading treatment or punishment. The appeal concerned the dispersal of a peaceful protest of about 30 individuals on 20 September 2013 and the brutal repression of a group of 25 individuals on 22 September 2013, including women and children, by law enforcement officials. At least 10 people suffered injury. Concerns were expressed that the dispersal of those protests by law enforcement officials infringed to the exercise by protestors of their rights to freedom of peaceful assembly and of opinion and expression.

29. Another joint urgent appeal was sent on 1 October 2013 with the Chair-Rapporteur of the Working Group on Arbitrary Detention, the Special Rapporteur on the promotion and protection of the rights to freedom of opinion and expression, the Special Rapporteur on the rights to freedom of peaceful assembly and of association, the Special Rapporteur on extrajudicial, summary or arbitrary executions and the Special Rapporteur on torture and other cruel, inhuman or degrading treatment or punishment. The communication addressed the death of Mao Sok Chan and the arrest of at least six individuals on the margins of protests held by CNRP, starting on 15 September 2013, in Phnom Penh. On the evening of 15 September, at the Kbal Thnal Skybridge, a group of rioters opposed police forces, resulting in major clashes. Security forces fired smoke grenades and live ammunition into the crowd. Mao Sok Chan, a bystander returning home from work, was shot and died on the scene. Nine persons were seriously injured. Several individuals, including teenagers, were beaten severely with truncheons by security forces. Subsequently, at least six persons were beaten and arrested, five of whom were allegedly coerced into confessing to participation in the riots. Grave concerns were expressed about the alleged indiscriminate and excessive use of lethal force against civilians, and the arrest and detention of the six individuals who reportedly did not take part in the incident.

30. On 17 February 2014, a joint allegation letter was sent with the Special Rapporteur on the promotion and protection of the right to freedom of opinion and expression, the Special Rapporteur on the rights to freedom of peaceful assembly and of association and the Special Rapporteur on the situation of human rights defenders. The letter addressed the ban on demonstrations imposed on 4 January 2014, when hundreds of police and military officers cleared the demonstration facilities in Freedom Park in Phnom Penh, just before three days of demonstrations planned and announced by CNRP.

31. On 28 February 2014, an urgent appeal was sent jointly with the Chair-Rapporteur of the Working Group on Arbitrary Detention, the Special Rapporteur on the promotion and protection of the right to freedom of opinion and expression, the Special Rapporteur on the rights to freedom of peaceful assembly and of association, the Special Rapporteur on the situation of human rights defenders, the Special Rapporteur on extrajudicial, summary or arbitrary executions and the Special Rapporteur on torture and other cruel, inhuman or degrading treatment or punishment. The appeal drew attention to clashes between the security forces and the demonstrators who were calling for an increase in the minimum wage for garment workers which had resulted in at least four deaths ${ }^{3}$ and several injuries, and the arrest and detention of 23 individuals in protest activities in early January 2014. Concerns were expressed about the alleged indiscriminate and excessive use of force against the protestors, resulting in deaths and injuries, as well as their arbitrary arrest and incommunicado detention. An investigation committee was reported to have been established, although concerns were expressed regarding the independence and legitimacy of the investigation. At the time of drafting, no results had been announced. Further

\footnotetext{
3 Since the date of the communication, as outlined above, a fifth man died as a result of his injuries
} from a beating by police at Veng Sreng on 3 January 2014 
concerns were expressed regarding the physical and psychological integrity of those in detention.

32. On 20 May 2014, a joint allegation letter was sent with the Special Rapporteur on the promotion and protection of the right to freedom of opinion and expression, the Special Rapporteur on the rights to freedom of peaceful assembly and of association and the Special Rapporteur on the situation of human rights defenders. The letter referred to alleged acts of intimidation and threats against Vann Sophath, a staff member of the Cambodian Center for Human Rights. Concern was expressed at the intimidation and threats of violence targeting Mr. Sophath while carrying out his peaceful work promoting and protecting the rights of the families on the disputed land.

33. The sole response to these communications to date is a note verbale from the Permanent Mission of Cambodia in Geneva dated 19 February 2014 acknowledging receipt of the allegation letter dated 17 February 2014 and making reference to a press release and Law on Peaceful Demonstration previously issued by the Government.

\section{Reform of the judiciary}

34. The report of the Special Rapporteur to the fifteenth session of the Human Rights Council in 2010 focused on the judiciary $(\mathrm{A} / \mathrm{HRC} / 15 / 46)$. Four years on, the Special Rapporteur has sought to assess the status of implementation of the recommendations contained in that report.

35. The Special Rapporteur was initially encouraged by the assurances repeated in January 2014 by the Prime Minister that three long-awaited fundamental laws on the judiciary (on the organization of courts, on the status of judges and prosecutors and on the Supreme Council of the Magistracy) would be tabled before Parliament in the near future. The Special Rapporteur was also encouraged by the announcement made to him that the reform would be more ambitious than that aimed for in his recommendations.

36. However, the Special Rapporteur is deeply concerned that recent attempts at judicial reform have been undertaken without prior public release of the draft laws and without consultations with relevant stakeholders. Despite repeated calls from civil society, development partners and the Special Rapporteur himself, ${ }^{4}$ the texts of the draft laws were not shared until the day before the National Assembly started to examine them. The Special Rapporteur is not aware of consultations of any kind that were organized on the texts finally submitted to the Council of Ministers or to Parliament. In May and June, the three draft laws were adopted in quick succession, with little debate, by the National Assembly and the Senate, ruled to be constitutional by the Constitutional Council two and a half weeks later, and promulgated into law on 16 July 2014.

37. The main purpose of the three laws should be to protect and promote the independence of the judiciary. Having examined the texts, the Special Rapporteur is concerned that the laws adopted by Parliament contain certain provisions that are detrimental to the principle of the separation of powers. The laws give the Ministry of Justice undue influence over the court system and the judiciary. In particular, the Minister of Justice remains a member of the Supreme Council of Magistracy and, moreover, will have the prerogative to appoint another member of the Council. The Supreme Council of Magistracy is the guardian of the independence of the judiciary in that it decides on all

4 "Cambodia: Lack of consultation on key laws sets worrying pattern for future legislation, warns UN expert", press statement, 27 May 2014. Available from www.ohchr.org/RU/NewsEvents/Pages/DisplayNews.aspx?NewsID=14648\&LangID=E. 
issues related to the appointment, transfer and promotion of judges. The Supreme Council also receives complaints and takes disciplinary actions against judges. The executive should have no role to play in such matters. In addition, the Special Rapporteur had previously recommended that judges and prosecutors should not be active members of a political party (A/HRC/15/46, para. 67) and had hoped that the law on the status of judges and prosecutors would spell out a requirement to that effect much more explicitly.

38. The Special Rapporteur is most concerned that the Law on the Status of Judges and Prosecutors will ultimately inhibit the ability of the justice sector to reform from within by requiring prior approval from the Supreme Council of Magistracy before a judge or a prosecutor can publicly express himself or herself on issues related to their work. While judges and prosecutors should clearly not comment on the cases before them, they should not be prevented from contributing to debates on matters of public interest relating to the law, the administration of justice and the judiciary.

39. The Special Rapporteur, however, also acknowledges some positive advances in the three laws. He recognizes the value of establishing regional appeals courts and of the inclusion of a higher proportion of elected judges and prosecutors to serve on a full-time basis on the Supreme Council of the Magistracy than is the case at present. Recalling that two of the three laws were envisaged in the 1993 Constitution, he welcomes their longoverdue adoption, despite the flaws outlined above. Setting out in binding law the requirements for the organization of courts, the status of judges and prosecutors, as well as the composition and operation of the Supreme Council of the Magistracy, the laws will serve to fill an important legal void.

40. The performance of the judiciary in practice demonstrates that there is a long way to go. In the case of the seven CNRP Members of Parliament elect and one supporter who were arrested in relation to the incident of 15 July 2014, the lack of material evidence needed for their arrests on very serious charges and their speedy release on the evening of the successful negotiations between the two parties on 22 July clearly reveal the extent to which the judiciary continues to be influenced by the executive. This experience demonstrates the urgency of the task of implementing and improving the three laws so that the judiciary will finally be able to serve its intended purpose: to render justice in an independent and impartial manner.

\section{Reform of Parliament}

41. In his 2011 report to the eighteenth session of the Human Rights Council (A/HRC/18/46), the Special Rapporteur outlined a series of measures relating to the Parliament that he considered critical for the process of democratization in the country. Many of them concerned specific matters that directly impact on the ability of the Parliament to function properly, to enact laws that promote and protect human rights, to be accessible to its diverse constituency and to be a model for society in promoting a culture of constructive criticism and popular participation. The Special Rapporteur is of the view that speedy parliamentary reform is also essential to enable the opposition to formally play a meaningful role as an opposition in Parliament. He looks forward to seeing a specific reform plan agreed upon by the two parties being made public as soon as possible.

42. The Special Rapporteur reiterated his main recommendations for parliamentary reform during his mission in June 2014 and called upon Parliament to henceforth be more transparent and open to consultations as part of its work. Specifically, he called on the parliamentary commissions to assume their roles in reviewing the compliance of domestic laws with international standards and regularly review government regulations and practices against the original laws to which they were intended to give effect. 
43. Several draft laws with potentially profound implications for democratic expression and participation are reportedly in various stages of elaboration, including on associations and non-governmental organizations, on trade unions and on cybercrime, in addition to the much-awaited laws by which electoral and other reforms will eventually be enacted. The Special Rapporteur once again calls on the Government and Parliament to ensure openness and transparency in the legislative process.

\section{E. Electoral reform}

44. The subject of the Special Rapporteur's report to the twenty-first session of the Human Rights Council (A/HRC/21/63) was on electoral reform. Regrettably, most of the recommendations contained therein were not implemented before July 2013 elections. The National Election Committee announced that 9.67 million Cambodians would be eligible to cast their ballots in 19,009 polling stations to elect the 123-seat parliament by proportional representation. The elections were contested by eight political parties. Only two parties won seats, the ruling Cambodian People's Party, and the opposition CNRP. They were closely contested elections, with conflicting claims as to which party won the largest share of votes, and thus seats in the National Assembly, giving rise to a dispute concerning alleged irregularities during the elections which lasted for nearly one year.

45. With the two winning parties having found a way to assume their seats in the National Assembly and discuss their differences there, the Special Rapporteur notes that priority will be placed on thoroughly reforming the electoral system to ensure that the next elections will not be marred by similar disputes. He is pleased that his recommendations on electoral reform have now become part of the national agenda, including that of according an independent institutional status to the National Election Committee. However, the Special Rapporteur stresses that there remains a great deal to be achieved before the public can regain confidence in the electoral system.

\section{F. Land rights}

46. Regarding the recommendations in the report on economic and other land concessions submitted to the twenty-first session of the Human Rights Council in 2012 (A/HRC/21/63/Add.1), the Special Rapporteur notes the positive developments resulting from the private land-titling programme of the Government led by the Prime Minister himself. In particular, he welcomes the land-titling programme undertaken under directive No. 001, which was designed to provide tenure security for marginalized and vulnerable communities, as well as the halt in granting new economic land concessions and the review of existing economic land concessions provided for under the Government's order No. 01 of the Government. He further welcomed the progress made by the Government in developing policy relating to land and housing rights, including drafting the National Housing Policy, a white paper on land policy and a draft environmental impact assessment law.

47. The Special Rapporteur notes with appreciation the information received from the Minister of Land Management, Urban Planning and Construction, Im Chhun Lim, with whom he met during his visit to the country in June 2014, according to which, some 3.5 million titles had been issued and some 180,000 parcels of land were being processed. The Special Rapporteur welcomed the adoption on 9 May 2014 of the long-awaited National Housing Policy, by which a process for the allocation of social housing was established and whose implementation he will observe with great attention. He also noted with satisfaction the significant attention given to land and housing rights issues in Cambodia in the National Strategic Development Plan 2014-2018. He has furthermore been made aware of and 
welcomed the initiatives of several authorities at the municipal and provincial levels to involve affected families and communities in local land management decisions, including decisions on resettlement. He is encouraged by the information he received concerning the land reform efforts being undertaken under the leadership of the new Minister of the Environment, Say Samal, including the retraction of some land concessions that were not developed according to plan. The Special Rapporteur notes with satisfaction the Minister's reported openness to working with civil society and other partners.

48. Despite the assurances that the land policies were being executed in full accordance with the law, the Special Rapporteur continued to receive large numbers of petitions from individuals and families describing being victim to forced eviction. While the recent policies and plans hold promise for a resolution to land disputes, they have, to date, been plagued by a serious lack of transparency, accountability and the absence of an effective dispute resolution mechanism.

49. The information brought to the attention of the Special Rapporteur concerning the cadastral commissions and the National Authority for Land Dispute Resolution from across the country consistently points to a lack of effectiveness, impartiality and credibility; he has been unable to find a single study that indicates the contrary. The National Authority has proven to be largely ineffective in settling land disputes. Although its composition should also include non-governmental organizations, civil society groups have declined to participate due to a lack of faith in the institution's independence and effectiveness. The Government and the judiciary are often unwilling or unable to regulate the conduct of private enterprises involved in the agribusiness and fail to provide redress for violations committed by private enterprises. Many cases submitted to the courts by victims of forced evictions remain unheard years after complaints were originally filed. The continued nexus between powerful business elites, political figures and the military, combined with the absence of an independent judicial system and ineffective dispute resolution mechanisms, continues to deny many ordinary Cambodians redress for violations of their fundamental rights or judicious settlement of disputes.

50. Notwithstanding the great efforts of the Government to address land disputes, and without prejudice to the merits of the claims, the scale of the problem and the tremendous underlying sense of injustice, anger and desperation expressed by affected persons to the Special Rapporteur underscore the need for an independent institution empowered to resolve land disputes on the basis of a reasoned historical review of the circumstances of each individual, family, or community claiming unfair treatment and resolution of their plight. The blanket dismissal of many such claims on the grounds that people are simply illegally occupying State land or the land of others fails to address the claims of many that they were forcibly evicted on earlier occasions, leaving them little choice but to move elsewhere, whether legally or illegally. It also contravenes the human right to adequate housing, which belongs to all persons, including illegal occupants of land.

51. The Special Rapporteur is of the view that nearly all the recommendations presented in his report on land rights continue to be relevant and calls upon the Government to once again review them with a view to implementing them. The Special Rapporteur supports maintaining the moratorium on new economic land concessions until a sound policy that addresses the human rights impact of such concessions is properly implemented. He also stresses the need to ensure that resettlement sites be fully prepared for human habitation before persons are relocated there, including by ensuring the availability of clean water, sanitation facilities, health and education services, and opportunities for earning a livelihood. Too many relocation sites, including those visited during his last mission in June 2014, reveal little or no such preparations even years after relocation took place. He draws attention to the relevant international standards in that regard and calls upon all levels of Government to abide by them scrupulously. 


\section{G. Emerging issues}

\section{Racism}

52. Over the reporting period, the Special Rapporteur learned of various incidents and many public pronouncements that appear to have been motivated by racial factors. $\mathrm{He}$ is concerned by the undertone of anti-Vietnamese rhetoric in particular, which appears to have some resonance in society, fuelled by widely held beliefs about historical events. In a press statement issued on 16 January $2014,{ }^{5}$ he reiterated his call on the opposition party to refrain from making pronouncements that enflame such sentiments.

53. The Special Rapporteur reiterates his concern about anti-Vietnamese racism, which periodically results in attacks against persons thought to be ethnic Vietnamese. He recalled that most of the few acts of violence or high tensions on the day of the elections in 2013, such as the brutal mob attack against one man in the Steung Meanchey district of Phnom Penh and ethnic Vietnamese being physically prevented from casting their votes in Sa Ang district, Troeuy Sla Commune, in Kandal Province, were motivated by such racism. The Special Rapporteur also recalls that, on 3 January 2014, at the scene of violent clashes earlier that day near Veng Sreng road, several ethnic Vietnamese-owned establishments were reportedly attacked and looted. He calls upon all those in positions of leadership to lead the way in promoting racial harmony and mutual understanding and on all Cambodians to refrain from treating others with violence for any reason, particularly for reasons based on race.

\section{Returning migrant workers from Thailand}

54. During his mission in June 2014, the Special Rapporteur was alerted to the return during the preceding days of over 225,000 Cambodian migrant workers and their families from Thailand in less than two weeks, and the reports of several deaths in the process. He commended the prompt efforts by the Government of Cambodia, at both national and subnational levels, to transport people from the border areas back to their communities and to assist the returnees in the process reintegrating at home and obtaining legal re-entry into Thailand for those that seek it.

55. The Special Rapporteur expressed his view that the Thai authorities should investigate the reported deaths of the Cambodians in Thailand and ascertain the reasons behind the sudden return of such large numbers of Cambodians. He also called on the Thai authorities to similarly investigate another concern, namely the deaths of Cambodian loggers over recent years.

56. He notes the efforts of both Governments to facilitate the legal return to Thailand of the migrant workers who wish to do so in such a way as to better protect them against trafficking and other human rights abuses. He commended the specific measures taken to regularize the legal status of workers who wish to go abroad, which included reducing the costs of obtaining new passports and facilitating their issuance.

57. While other measures, such as the promotion of employment opportunities in Cambodia and the provision of vocational training to that end, appear to be measures for the longer term, he encouraged their implementation without delay to benefit those who may not wish to seek work abroad again.

\footnotetext{
5 Available from

www.ohchr.org/EN/NewsEvents/Pages/DisplayNews.aspx?NewsID=14175\&LangID=E.
} 


\section{Relocation of refugees}

58. The Special Rapporteur was informed by some civil society organizations about an imminent agreement between the Governments of Cambodia and Australia for Cambodia to receive refugees who aimed to claim asylum in Australia, but were intercepted by Australian authorities, then transferred, detained and processed in Nauru. He stresses that Australia, as a party to the Convention relating to the Status of Refugees of 1951 and the Protocol thereto of 1967, recognizes the right of persons to seek asylum from persecution in another country. In accordance with the 1951 Convention, asylum seekers should in principle have their claims processed in the country in which they arrive, or in procedures within the territory of the intercepting State. If found to be refugees, they should be offered protection there with the full rights under the Convention. Therefore, transferring its duties to another country, if that is the object and purpose of an agreement, could be a serious abdication of the responsibilities of Australia, particularly if it does not ensure that the accepting country meets essential protection standards. This is more so the case if the plan is to relocate them to a country for which the absorption of refugees may pose a far greater challenge than for the transferring country. Cambodia, while also a party to the Convention, is not on equal footing with Australia in terms of rights, opportunities and international standards of integration. Moreover, as past experience shows with the treatment meted out to Uighur asylum seekers from China, refoulement is not impossible.

59. The Special Rapporteur regrets that he was unable to hear the views of the Government of Cambodia about the issue owing to the unavailability of the Minister of Foreign Affairs and International Cooperation during his last visit. As the work on a bilateral agreement with Australia is reportedly advancing quickly, he takes the opportunity to remind both Governments that before any agreement is concluded and refugees are transferred to Cambodia, the latter must be prepared to offer refugees the opportunity to rebuild their lives in safety and dignity. States that do not have essential services in place are not ready to offer refugees a permanent solution through relocation.

60. In order to fully guarantee the rights under the 1951 Convention in law and practice, a sustainable relocation programme requires a solid legislative and policy foundation providing, among other things, permanent settlement for refugees and the opportunity for citizenship. Any relocation agreement needs to be put into practice by an adequately resourced integration programme which will provide the services and support needed by refugees to adjust to a new society. Integration programmes should include reception of refugees, accommodation, language training, education, vocational training, employment, health care and support for family reunification.

61. Cambodia has obligations to put such a programme in place irrespective of any agreement with another country, and should demonstrate that a programme is functional before entering into such an agreement.

62. The Special Rapporteur takes the opportunity to call upon Australia to abide by its obligations under the Convention to offer refugees the opportunity to rebuild their lives in safety and dignity, rather than export that responsibility to another country.

\section{Universal periodic review of Cambodia}

63. At its 37th meeting, on 26 June 2014, the Human Rights Council considered and adopted the outcome of the review of Cambodia conducted during the eighteenth session of the Working Group on the Universal Periodic Review held from 27 January to 7 February 
$2014 .{ }^{6}$ Of 205 recommendations made, 163 were accepted by the Government and 42 were noted.

64. Between the review by the Working Group in January 2014 and the adoption of the outcome, Cambodia changed its position on eight recommendations from "accepted" to "noted", which the Special Rapporteurs regrettably believes reflects reluctance of the Government to accept and therefore commit itself to act on important human rights issues, including four that it explicitly "rejected". ${ }^{7}$ He notes that many of the recommendations noted in this round of universal periodic review are equivalent to some that it had accepted — and thereby committed itself to implement — in the first round in 2009.

65. The Special Rapporteur draws attention to the fact that some of the recommendations that Cambodia did not accept are actually binding obligations under human rights treaties ratified by Cambodia. Notably, the establishment of an independent national preventive mechanism is an obligation under the Optional Protocol to the Convention against Torture and Other Cruel, Inhuman or Degrading Treatment or Punishment, which Cambodia ratified in 2007. It is simply not an option to decline to establish an independent national preventive mechanism. Other binding obligations include ensuring the independence of the judiciary; freedom of expression and information, including on the Internet; freedom of assembly; prohibiting the use of excessive force against protestors during demonstrations; and adequate housing and access to basic services, health care and employment for those displaced from their land.

66. The Special Rapporteur recalls that States parties to international human rights treaties are under obligation to strive for and achieve the progressive realization of human rights; in other words, regression on treaty-defined human rights is not permitted. Therefore, he urges the Government of Cambodia to revisit the recommendations that it "noted", with a view to reaffirming its commitment to implement them.

\section{The independence of national human rights institutions}

67. The Special Rapporteur consulted with a wide range of stakeholders during his last two missions about their views regarding the need, or desirability, of establishing an independent national human institution. An independent national institution that conforms to the Paris Principles is responsible for monitoring and advising the Government on all human rights matters and is empowered to investigate individual complaints has proven to be an effective protection mechanism in many countries, including within the Association of Southeast Asian Nations. He considers that such an institution could also prove useful in filling an important gap in Cambodia.

68. While there seemed to be a widely shared consensus on the need for such a mechanism, concern was expressed in different quarters on whether it was possible under current conditions to create a truly independent national human rights commission and/or appoint truly independent people with the requisite credentials to serve as members.

69. The approach of the Government has been to establish governmental rather than independent bodies. The overarching institution is the Cambodia Human Rights Committee, which reports to the Council of Ministers. Other bodies that are focused on specific groups of persons have also been established, such as the Cambodian National Council for Women, the Cambodian National Council for Children and the Disability

${ }^{6}$ The report of the Working Group is contained in document $\mathrm{A} / \mathrm{HRC} / 26 / 16$.

7 Within the rules of the Council as stipulated by its resolution 5/1, they would be considered as merely "noted" since the rules do not provide for rejection. 
Action Council. Those bodies serve to help the Government to develop national policies in their areas of responsibility and were conceived to perform a coordination role within the Government. The national preventive mechanism created in 2009 , referred to above, is composed entirely of government officials. The fight against corruption is undertaken by the governmental Anti-Corruption Unit, which reports to the Council of Ministers.

70. Notwithstanding the useful and necessary functions of those governmental mechanisms, the Special Rapporteur believes that they do not take the place of independent institutions. State institutions need to be monitored internally and externally. The structures for internal assessment seem to be in place. Externally, independent institutions are best placed to provide senior policymakers with an honest assessment of reality without embellishment and the best options for action untarnished by institutional ties.

71. The Special Rapporteur was given to understand by the Government that a draft law on a national human rights institution had been under preparation for some time and that work on it would resume shortly. He stresses that it will only bring added value to the human rights infrastructure today if its independence is guaranteed, in full conformity with the Paris Principles.

72. While taking due account of such views, the Special Rapporteur is of the opinion that if all sides were committed to making it a success, work could commence for the establishment of such an institution. In many countries with fully fledged independent national human rights institutions, conditions for the initial establishment of those institutions were not always optimal from the outset, but progress was seen in due course.

73. Many individuals have told the Special Rapporteur that it is impossible for there to be a truly independent national institution in the current political context in Cambodia. However, the Special Rapporteur notes that one exception is the Arbitration Council, which has been able to preserve its independence and thus its credibility before the parties to most of the labour-management disputes brought to it. Although the results of arbitration are not binding, he understands that several major buyers and trade unions have accepted to be bound by the conclusions of the Arbitration Council. He further recommends that all those who have a stake in peaceful labour relations in Cambodia work together to ensure that the Council will continue to be adequately and sustainably resourced, with full guarantees for its continued independence.

74. Nevertheless, the Special Rapporteur recognizes that independence alone will not ensure the effectiveness of such institutions. Much will depend on other factors, such as the nature of their mandates, the level of human and financial resources allocated to them, the availability and willingness of qualified individuals whose independence is widely accepted to serve on those bodies and other principles set forth in the Paris Principles. However, those institutions' actual and perceived level of independence is central to their legitimacy, which is what would allow them to stand up for themselves in regard to the other substantive matters.

75. Work must begin immediately on improving existing institutions, whose independence (or lack thereof) has serious implications for the extent to which human rights are protected. They include the judiciary at all levels, the Cadastral Commission and the National Authority for Land Dispute Resolution, and those mechanisms mandated to resolve election-related disputes.

76. The Special Rapporteur notes that the establishment of other independent institutions is a legal obligation. He emphasizes that a fully independent national preventive mechanism empowered to prevent torture in law and in practice is required under the Optional Protocol to the Convention against Torture and Other Cruel, Inhuman or Degrading Treatment or Punishment and should be established without delay. Similarly, as a State party to the United Nations Convention against Corruption, Cambodia is bound to 
put into place one or more bodies to combat corruption effectively and "free from any undue influence". The current body under the executive branch of Government is in prima facie contradiction of that requirement. The Special Rapporteur strongly recommends that the Government seriously examine its obligations in relation to the independence of those institutions with human rights responsibilities, in line with international standards, and take immediate steps toward meeting them.

77. Finally, the Special Rapporteur notes with concern that the draft cybercrimes law shared informally with him envisages the establishment of a national anti-cybercrime committee with none of the guarantees of independence. He regrets being unable to confirm the validity of the text he saw, since the draft law has not been publicly released. In a country where the use of social media is prevalent, the potential threats to freedom of expression, association and peaceful assembly that could be posed by a body empowered to prosecute alleged offenders of cybercrimes are evident.

\section{Conclusions}

78. Cambodia stands at a crossroads. The Special Rapporteur has sensed the optimism and desire for change in the country, which is possible if it is underpinned by serious and comprehensive reforms of State institutions, as detailed in his previous reports to the Human Rights Council. The Special Rapporteur has received positive assurances that such reform will occur during his missions to the country and awaits anxiously their translation into action. Change is coming to Cambodia faster than many had anticipated. The challenge for the current political leadership within both of the main political parties is to embrace change and to find a way to manage it in the best interests of the country.

79. The Special Rapporteur urges the Government to continue strengthening the legal and institutional framework for human rights protection. He urges it to give effect to the human right to participate in public affairs by pursuing such efforts in open, participatory ways, giving due opportunity to the public to provide feedback and due consideration to all views thus submitted.

80. The recurring themes throughout the present report highlight the need for the independence of the national structures to promote and protect human rights, as well as greater transparency and participation in the way in which the country is governed. Ways must be found to adapt the multiple reforms under way to those needs. The year 2013 was the year in which the Cambodian people found their voice, and the Special Rapporteur is convinced that Cambodia has embarked on a new path from which there is no turning back.

\section{Recommendations}

81. The Special Rapporteur recommends that the Government of Cambodia undertake the following actions:

(a) Examine his recommendations as contained in his present and previous reports and respond to them, with a view to establishing a specific plan of implementation;

(b) Accelerate the process of establishing an independent national human rights institution in full compliance with the principles relating to the status of national institutions for the promotion and protection of human rights (the Paris Principles; 
(c) Reach a detailed agreement with the opposition on the promised reform of the electoral, parliamentary and other institutions responsible for upholding people's rights, and move to implement them without delay;

(d) Fully respect the freedom of expression of all stakeholders in Cambodian society and freedom of peaceful assembly at all times, refrain from suspending them in an arbitrary manner and, in that regard, officially lift the demonstration ban in law and in practice;

(e) Immediately bring all perpetrators of violence during demonstrations to justice, including members of the security forces who caused human death and injury, and ensure that adequate reparation is provided to the victims or their survivors;

(f) Renew its efforts aimed at legal and judicial reform, especially on improving the independence of the judiciary and its capacity to handle cases in a fair and expeditious manner and, in that regard, embark immediately upon amending the three fundamental laws on the judiciary to that end;

(g) Give effect to the right to participate in public life by clearly instructing all the ministries and any other State institutions to organize public consultations on draft laws and to release such drafts publicly, inviting comments from any interested member of the public, prior to submission to the Council of Ministers. That applies in particular to the draft laws reportedly under preparation on associations and nongovernmental organizations and cybercrimes, as well as all other draft laws that carry implications for the enjoyment of human rights;

(h) Undertake parliamentary reform, with a view to increasing transparency in the legislative process and ensuring the conformity of all draft laws that have human rights implications with international human rights standards;

(i) Ensure that the new mechanism to set the minimum wage takes into consideration the research necessary for evidence-based decision-making and regular revision, in particular setting a wage level sufficient to provide all workers and their families with a decent standard of living, as required by the International Covenant on Economic, Social and Cultural Rights, and to periodically review the national minimum wage so determined;

(j) Pursue public administration reform and, in doing so, establish a wage structure to ensure that public servants will be guaranteed adequate remuneration to provide for an adequate standard of living; establish clear performance indicators and accountability mechanisms for all public servants; and establish a programme to more vigorously combat corruption at all levels;

(k) Fully respect the trade union rights of all workers in Cambodia and protect trade unionists so that they are able to exercise their activities in a climate free of intimidation and risk to their personal security or their lives;

(l) Protect human rights defenders and especially those defending land rights and workers' rights, so that they may be able to carry out their work without intimidation or harassment;

(m) Refrain from using the judiciary to intimidate, harass and imprison human rights defenders and trade union representatives;

(n) Immediately resolve the existing disputes relating to land rights as a matter of priority, and ensure in law and in practice that new land concessions are granted only when the rights of the people affected by them are provided for; review all relocation sites to immediately bring them up to human rights standards and prohibit all forced relocations in the future to sites that do not meet those standards; 
(o) Review its position on those recommendations from the universal periodic review that are legal obligations on Cambodia as a party to international treaties, and take steps to implement all such recommendations as well as those explicitly accepted in law and in practice;

82. The Special Rapporteur appeals to all political actors in Cambodia to respect diversity and promote racial harmony and tolerance.

83. Furthermore, the Special Rapporteur recommends that the Government of Cambodia and the Government of Thailand continue to facilitate through legal channels the return to Thailand of the Cambodian migrant workers who wish to return, in a manner that increases their protection against trafficking and other human rights abuses.

84. Lastly, the Special Rapporteur recommends that the Government of Cambodia and the Government of Australia, as States parties to the Convention relating to the Status of Refugees, of 1951, take necessary steps to ensure that Cambodia is fully prepared to offer refugees the opportunity to rebuild their lives in safety and dignity in line with international standards, before any agreement is concluded and refugees are transferred to Cambodia. 